\title{
THE UNIFORM RECOGNITION ITEMS IN THE FINANCIAL STATEMENTS
}

\author{
Liana GĂDĂU \\ "Spiru Haret” University, Ion Ghica Street, no. 13, Bucharest, 030045, \\ Romania, Tel.: +40214551000, Fax: +40213143900, \\ Email: lianagadau@yahoo.com
}

\begin{abstract}
Through the issues presented and analyzed, we want to highlight the overwhelming importance of the recognition process of the elements in the financial statements, resulted in the recognition criteria, more or less detailed, depending on the chosen normalization framework, but which helps to the accurate positioning of items in the financial statements and thus the credibility and relevance of the information contained therein.

The necessity of normalization process of recognition of the elements in the financial statements appeared at different levels of the accounting referential, and here we refer particularly to the two basic referential: the international and the American one, which will constitute the basis of our analysis on this paper. The result of the normalization process of recognition of the items from the financial statements has been the establishment of the criteria for recognition, which contribute to proper positioning of elements in the financial statements, thus giving credibility and relevance to the information contained therein.
\end{abstract}

Keywords: the process of recognition of the elements; the criteria for recognition.

JEL Classification: $M 40, M 41$ 


\section{Introduction}

The necessity of normalization process of recognition of the elements in the financial statements appeared at different levels of the accounting referential, and here we refer particularly to the two basic referential: the international and the American one, which will constitute the basis of our analysis on this paper.

The approach of the process of recognition of the elements in the financial statement through various accounting referential

The general framework for the preparation and presentation of the financial statements - defines "recognition" as the process of incorporation in the Balance Sheet or the Profit and Loss Account of an article which first meets the definition of an element, and satisfies the following criteria: It is likely that any future economic benefit associated to enter or leave in/or from the enterprise; The article has a cost or value reliably measured.

We observed that the requirement of probability of future economic benefits highlights the definitions of elements, which are circumscribed to the existence of these benefits.

It should be noted that, while respecting the definitions of elements is not considered a criterion for recognition as the American Framework, it still remains the essential condition in recognizing an element in the Balance Sheet or the Profit and Loss Account.

IASB also states that an element which possesses the essential characteristics, but that does not meet the criteria for recognition, can bring information in the Annex to the Financial Statements. Such information becomes relevant when knowledge of these elements is considered useful for assessing the financial position, performance and the evolution of the financial position.

At the same time, the criteria for recognition involves the interplay between an element that meets the definition and the criteria for an ascertained fact (for example, an asset) to automatically assume the finding of another element (for example income or a liability). Also, IASB states that an element which at a certain moment does not meet the criteria for 
recognition in the financial statements can satisfy these criteria later, as a result of subsequent events and circumstances.

\section{The American conceptual framework}

On the other hand, the American conceptual framework places a strong emphasis on the recognition process of the elements in financial statements, in this sense leaving a distinct structure within the conceptual framework, namely SFAC 5 "Recognition and assessment in financial statements of commercial companies". SFAC5 defines recognition as the process of incorporating an element in the financial statements, an element that meets certain criteria for recognition, the incorporating of an item in the financial statements involving both a descriptive and numeric form, as in the case of IASB Framework.

It should be noted that the criteria for recognition of an element proposed by the FASB in the financial statements are far more detailed than those required by the IASB, but these criteria must be applied in the limits imposed by the relationship cost-benefit and materiality level.

The criteria for recognizing states: The definitions: an element to be recognized in the financial statements must first meet the definitions set out in SFAC6 "Elements of financial statements"; The assessment (measurement): information corresponding to that item should be useful for decision-making by users; The credibility (reliability): information relating to the item must be sincere (true), verifiable and neutral.

However, SFAC5 states that the recognition process includes the initial recognition, the later modifications and the un-recognition (elimination from the financial statements of that element).

The IASB Framework establishes as first criteria for recognition the concept of probability. It is used in conjunction with the uncertainty level in which the future economic benefits associated with the item will affect the benefits or losses.

The evaluation of uncertainty level refers at the information available at the time when the financial statements are drawn up.

To understand the concept presented, the correlation probabilityuncertainty presents the following example: when a claim is likely to be 


\section{Issue 4/2015}

charged is justified, in the absence of any evidence to the contrary (and therefore virtually no uncertainty) and the claim is recognized as an asset.

In the event that the number of claims is high, it is quite probable (so it feels a slight increase in the degree of probability) that some claims cannot be cashed, so the appearance of a certain amount of not receiving the money (in conjunction with a slight increase of the uncertainty level), a situation where the economic benefits of recognizing will be reduced.

On the other hand, the American conceptual framework does not define a distinct concept of probability among the criteria for recognition, but this is induced by the definitions of the elements set by the framework for the following elements that will be recognized in the financial statements.

The second condition that an element must satisfy to be recognized in the financial statements, a condition which can be found in both referential, more or less detailed, is that the item must have a cost or value that can be measured reliably.

This concept is shown in more details in the American framework, through the following three characteristics of the referential: evaluation, relevance, credibility. The two quality characteristics (relevance and credibility) come to create the context in which the assessment takes place, in terms of both its nature, by finding the most appropriate basis for the item concerned, and in terms of its size, by finding a value that is representative for the company that presents that element. In many cases the cost or value must be estimated. The use of reasonable estimates is an essential part of preparing the financial statements and does not influence their credibility. If it cannot be made a reasonable estimate, the item will not be recognized in the Balance Sheet or the Profit and Loss Account, but may be presented in the Information Notes about that item, especially if they are relevant to assessing enterprise's financial position, performance, or modification of the financial position.

The concept of probability used in the criteria for recognition is accompanied by a degree of uncertainty about future economic benefits associated. Therefore, we can say that the assessment of probability level of generating future economic benefits has a significant influence in the 
recognition process and the correct establishment of an element in the financial statements. The best examples are the provisions, liabilities and contingent liabilities, where the degree of probability makes the difference between these elements.

As a basis of analysis we will use the rules of IAS 37 "Provisions, contingent liabilities and assets", but also the Finance Order no. 1802/2014 regarding the Approval of the Accounting Regulations on the annual individual and consolidated financial statements.

The standard states that the uncertainty related to the chargeability and the size of the final amount is the one which makes the difference between reserves and debts.

According to IAS 37, the provisions are defined as doubtful debts in terms of chargeability moment, or the corresponding amount, thus having a probable character.

What interests us is their correct positioning in the financial statements for the information to be relevant and credible. This standard offers the necessary guidance, specifying that the provisions are recognized in the balance sheet - if these conditions are met: The entity has a present obligation (legal or constructive) resulting from a past event; It is likely that an outflow will affect the future economic benefits in order to honour the current obligation (there are more changes to happen than not to happen), meaning that the probability of generating future economic benefits is high, to be noted that this criterion of recognition is essential in positioning the provision in the balance sheet; The amount of obligation can be estimated reliably (IAS 37 specifies that only in very rare cases cannot be a reliable estimate of the amount of the obligation).

A contingent liability is an obligation likely to emerge as a result of past events and whose existence will be confirmed only by the occurrence or non-occurrence of uncertain future events that may not be entirely under the control of the entity, or an obligation incurred in the current past events. The question that interests us is whether the contingent liability can be recognized in the Balance Sheet, in the conditions presented above. Because it does not meet all the criteria for recognition, in the sense that: Even if it is a general obligation of past events; Is not likely that outflow of resources 

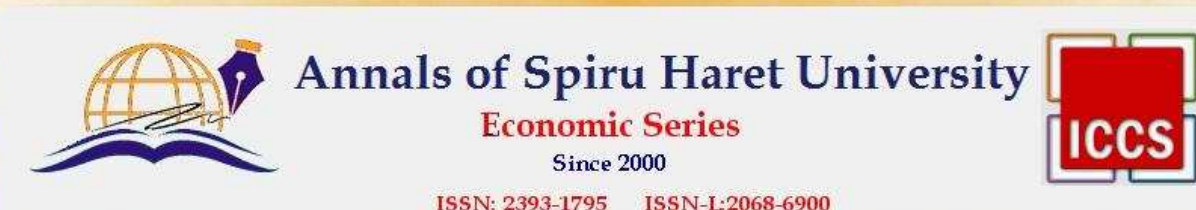

Issue 4/2015

which would incorporate future economic benefits to happen, meaning that the probability of generating future economic benefits is low; and The amount of obligation cannot be evaluated sufficiently credible, under these conditions in the Notes to the financial statements are given information regarding the existence of contingent liabilities, especially since the information generated by it are important in determining the financial position, financial performance and changes in the financial position.

The current national legislation - the Finance Order no. 1802/2014 regarding the Approval of the Accounting Regulations on the annual individual and consolidated financial statements defines in the same way these elements and their criteria for recognition in the financial statements. Thus, the order defines the contingent liabilities in the same manner and states that they will not be recognized in the Balance Sheet, just off the Balance Sheet, being presented in the Explicative Notes. The contingent liabilities are assessed continually to determine whether it has become probable an outflow of resources which incorporates economic benefits. When an outflow of resources, generate by an event considered previously a contingent liability, is necessary, a debt or a provision will be recognized in the financial statements for the period in which this change appeared. The order clarifies the conditions under which contingent liabilities are distinguished from provisions, namely: The provisions are recognized as liabilities (and recorded in the Balance Sheet) as they are current liabilities on the Balance Sheet and it is probable that an outflow of resources will be required to settle the obligations; The contingent liabilities are not recognized as liabilities (related information appear in the Explicative Notes) because they are obligations that must be possible to confirm whether the entity has a present obligation that may lead to an outflow of resources, or they are current obligations, but do not qualify for recognition in the Balance Sheet.

\section{Conclusions}

Through the issues presented and analyzed, we want to highlight the overwhelming importance of the recognition process of the elements in the financial statements, resulted in the recognition criteria, more or less 


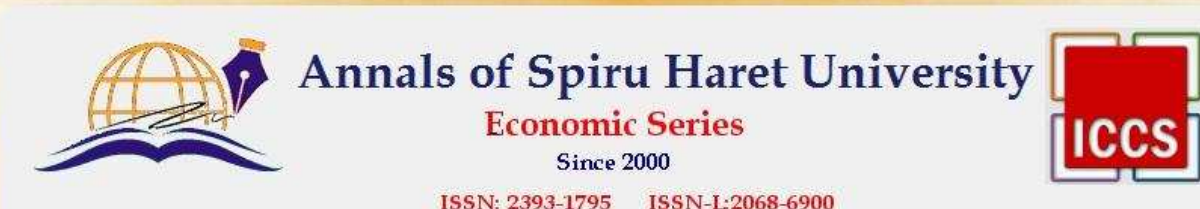

Issue 4/2015

detailed, depending on the chosen normalization framework, but which helps to the accurate positioning of items in the financial statements and thus the credibility and relevance of the information contained therein.

\section{References}

1. *** IAS 37"Provizioane, active şi datorii contingente"

2. *** The Finance Order no. 1802/2014 regarding the Approval of the Accounting Regulations on the annual individual and consolidated financial statements.

3. Gădău, L., Intocmirea, prezentarea şi utilizarea situaţiilor financiare. Studii şi cercetări (Bucureşti: Editura Tribuna Economică, 2014).

4. Glăvan, E.M., et al., Contabilitate financiară (Bucureşti: Editura ASE, 2013).

5. Greceanu, C.V., Contabilitatea aplicată a întreprinderii şi microintreprinderilor (Bucureşti: Editura Universitară, 2014).

6. Iacob, P. and Gheorghe, B., Contabilitatea Financiară (București: Editura Intelcredo, 2014).

7. IASB, Standardele Internationale de Raportare Financiară (București: Editura CECCAR, 2015).

8. Nobes, Ch. and Parker, R., Comparative International Accounting (FT Prentice Hall, 2008).

9. Ristea, M. and Dumitru, G., Contabilitatea societăţilor comerciale Vol. I-II (Bucureşti: Editura Universitară, 2009).

10. Tabară, N. and Horomnea, E., Contabilitate internaţională (Iaşi: Editura TipoMoldova, 2010). 
